\title{
Detection of Powdery Mildew (Podosphaera xanthii (Castagne) U. Braun \& N. Shishkoff) Resistance Gene in Melon (Cucumis melo L.) Cultivar Tacapa Green Black
}

\author{
Annis Fatmawati", Budi Setiadi Daryono \\ Laboratory of Genetics and Breeding, Faculty of Biology, Gadjah Mada University, Indonesia
}

Copyright $(2016$ by authors, all rights reserved. Authors agree that this article remains permanently open access under the terms of the Creative Commons Attribution License 4.0 International License

\begin{abstract}
Melon (Cucumis melo L.) is one of excellent horticultural commodities in Indonesia. The seed's demand rises in every year due to the increase of people's avocation. However, in the production, melon faces many problems. One of them is Powdery Mildew attack. Consequently, it is needed to create a new cultivar that has gene against the attack. Tacapa Green Black (GB) was one of cultivars developed by Laboratory of Genetics and Breeding, Faculty of Biology, Universitas Gadjah Mada. Tacapa GB was derived between PI 371795 and Act3 434 with a test cross Act3 434. The goal of this research was detection of a powdery mildew resistance gene. It was conducted using Sequence Characterized Amplified Regions (SCARs) analysis. The comparator cultivars used in this research were Tacapa Silver, Action 434, and Aramis. The result showed that Tacapa GB had a resistance gene of powdery mildew. It was proven with DNA band at 1058 base pair (bp). Based on this result, it could be concluded that Tacapa GB was excellent melon because of an ability in facing Powdery Mildew problems naturally. Furthermore, because of the presence of that gene, it could reduce the using of pesticide which was commonly used by Farmers to handle fungi attack.
\end{abstract}

Keywords Tacapa GB, Powdery Mildew, SCARs

\section{Introduction}

Melon (Cucumis melo L.) is one of excellent horticultural commodities in Indonesia. The fruits consumption increases substantially owing to the rise of inhabitant's number, inhabitant's income, and changes of people's foodstyle that needs fresh fruits as their daily health intake [1]. Besides, the seed's demand grows considerably in every year which is marked by the growth of melon production in Indonesia. Based on the data given from Badan Pusat Statistika (BPS), the melon production reached 85,161 ton in $2010,103,840$ ton in $2011,125,474$ ton in 2012, and 125,207 ton in 2013 [2].

Tacapa Green Black (GB) is one of the cultivar developed by Laboratory of Genetics and Breeding, Faculty of Biology, Universitas Gadjah Mada, Indonesia. Tacapa GB was derived between PI 371795 and Act3 434 with a test cross Act3 434. The previous experiments indicated that PI 371795 had gene resistence of Powdery Mildew [3]. Hence, it forecasts that Tacapa GB inherits this superior character.

In the production of melon, the fungi infection and phatogen are big problems that are difficult to handle [4]. Powdery Mildew is one of fungus that infects melon. It belongs to order of Erysiphales. The species that is commonly found in melon is Podosphaera xanthii. The main character of this disease is the emergence of white grey spot in a surface of leaves. The form and size are smaller than the pin and spherical structure. It grows individually or clusterly [5].

The effect of this disease is a drop of fruits quality and fruits productivity reaching $20-40 \%$. It is caused by powdery mildew attack which disturbs totally the physiology process of that plant [6]. In addition, fruits become premature, small, unsweet, untasty aroma, and easily rotten [7]. People usually use pesticide to tackle this annoyance. Whereas, the pesticide has negative impact for the environment. Hence, if the gene against the fungi is found, so it can reduce the using of pesticides.

Sequence Characterized Amplified Regions (SCARs) is DNA fragment amplified by PCR method using specific primer along 15-30 base pair (bp). SCARs is resulted by the development of RAPD marker and added by oligonucleotide. SCARs is dominant gen that can be changed become codominant gen by cutting the gene using restriction enzyme. The benefit of SCARs rather than RAPD is that it can appear single strand DNA $[8,9]$.

\section{Materials and Methods}




\section{The preparation of gene detection against Powdery Mildew attack}

Four melon cultivars (Tacapa Green Black (GB), Tacapa Silver, Action 434, and Aramis) were used in this study. Their seeds were germinated in a tray that was surfaced by wet newspaper. Afterward, the seeds were stored for 24 hours in room temperature until they germinated, marked by emerging of radicula. This was followed by planting the shoot to the polybag and transfering it to the field. After reaching 3-4 weeks, the melon's leaves could be collected to isolate its DNA. The leaves were fed to the plastic and stored in the freezer in $-20^{\circ} \mathrm{C}$.

\section{Detection of Powdery Mildew Resistance Gene \\ DNA Extraction}

In the first stage, leaves were weight as 0.4 gram, after which it was grinded using mortar that had been stored in the refrigerator. Following this, reagent of phytopure I was fed to the mortar slowly and then grinded together with leaves. The mixture was fed to the tube $1.5 \mu \mathrm{l}$ and added reagent of phytopure II as $100 \mu \mathrm{l}$. Then, it was shaken slowly before it was incubated in $65^{\circ} \mathrm{C}$ for 15 minutes. It was stored in refrigerator for 20 minutes. The solution was then added 400 $\mu l$ cold cloroform and shaken slowly before it was added by $30 \mu \mathrm{l}$ phytopure resin. The mixture was centrifuged during 5 minutes with velocity of $3000 \mathrm{rpm}$. The supernatan was moved to the 1,5 $\mathrm{ml}$ tube and then fed using cold isopropanol as many as supernatan's volume. Over the next stage, the mixture was shaken, hushed during 5 minutes, and centrifuged with velocity of $10,000 \mathrm{rpm}$ in 10 minutes. Afterward, the supernatan was throwed and remained the DNA pellet in the bottom of the tube. Then it was washed through $100 \mu$ l of etanol $70 \%$ and centrifuged again by the velocity of 10,000 for 5 minutes. This was repaeted 3 times. Next, etanol was throwed, pelet was dried before adding 50 $\mu 1$. $1 \mathrm{xTBE}$ buffer. Then, it was saved in $-20^{\circ} \mathrm{C}$ and ready to be analysed quantitavely.

\subsubsection{The Measurement of DNA Concentration}

The DNA concentration was measured using spectrophotometer UV-VIS. Firts of all, spectrophotometer was settled in $260 \mathrm{~nm}$ wave length. Spectrophotometer was calibrated with aquabides through pressing auto zero button. When zero number appeared, aquabides was changed using isolated and dilluted DNA, then its absorbance was measured in $260 \mathrm{~nm}$ wave length and the number was noted. Next, the measurement was repeated in $280 \mathrm{~nm}$ wave length and the number was noted. DNA concentration was measured by this formula:

DNA Concentration $=$ Absorbance of $\lambda 260 \mathrm{~nm} \times 50 \mathrm{x}$ dillution $(\mu \mathrm{g} / \mathrm{ml})$

\subsubsection{DNA Amplification}

DNA amplification was done through PCR method using SCAR primer. The process commenced when all of components of reaction comprised of faststart $12,5 \mu \mathrm{l}$, primer forward 2,5 $\mu$ l, primer reverse $2,5 \mu 1$, DNA sampel $1 \mu \mathrm{l}$, and akuabides $6,5 \mu \mathrm{l}$ were fed to one tube and then mixed smoothly. Following this, PCR machine was settled by the formule of predenaturation $95^{\circ} \mathrm{C}$ for 5 minutes, denaturation $95^{\circ} \mathrm{C}$ for 1 minute, annealing $56^{\circ} \mathrm{C}$ for 1 minute, extension $72^{\circ} \mathrm{C}$ for 2 minutes and post extension $72^{\circ} \mathrm{C}$ for 10 minutes. The process was repeated 34 times. Ultimately, the PCR products were saved in freezer $-20^{\circ} \mathrm{C}$.

\subsubsection{Electrophoresis}

First of all, gel agarose was made as media of DNA separation. The machine was filled by 1 XTBE until the gel agarose sinked. PCR products $(5 \mu \mathrm{l})$ were fed to well. The first well was filled with marker, whereas the following wells were filled by samples. Afterwards, the well was placed in the electrophoresis machine. The power supply was managed at 100 volt for 30 minutes, then, the ON button was pressed. Eventually, the result was observed in the UV transilluminator.

\subsubsection{Tenacity time}

All cultivars were saved in room temperature to examine their tenacity facing natural condition.

\section{Results and Discussion}

\subsection{Qualitative and Quantitative test of Isolated DNA}

The goal of this test was to detect the purity, concentration, and existence of extracted DNA. While, quantitative test was conducted by spectrophotometry method using 260 and 280 $\mathrm{nm}$ wave length, the qualitative test was carried out by electrophoresis method.

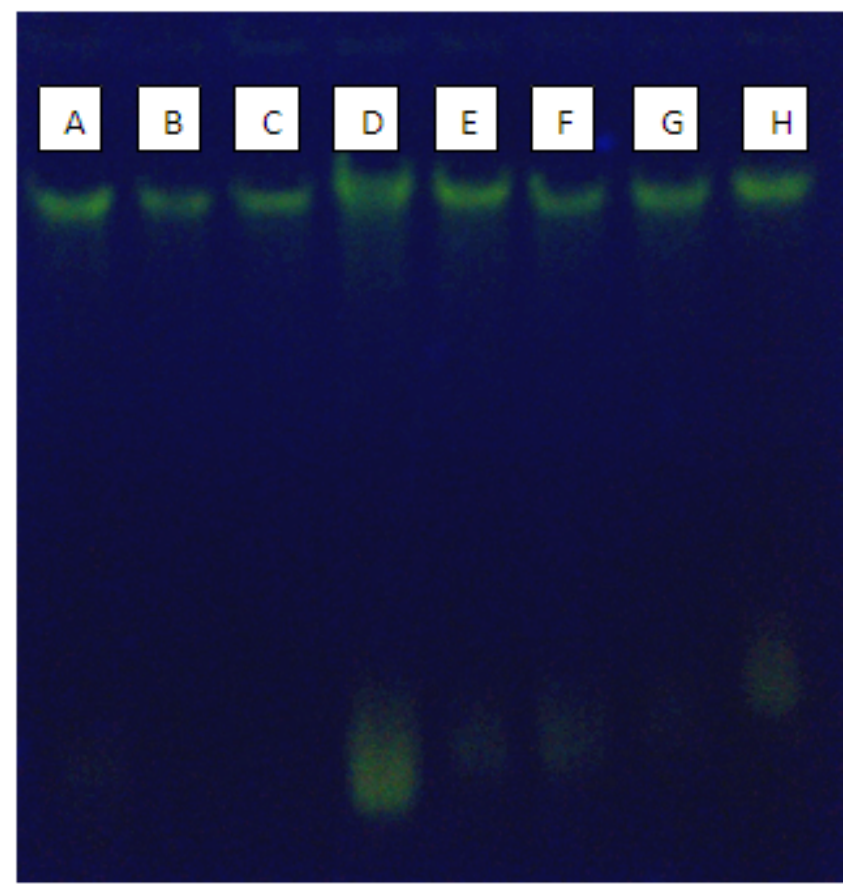

Figure 1. The presence of smear in the sample; A,B: Tacapa GB; C,D: Tacapa Silver; E,F: Action 434; G,H: Aramis 
Qualitative test detects the existence of the genom in the DNA. If the sample contains genom, so it will emerge smear in the agarose gel seen by UV transilluminator. By contrast, if the genom is absent, so smear will not appear. The result is that all samples carry the genom due to the presence of smear (figure 1)

Quantitative test detects the purity and concentration of DNA. The DNA sample is stated as pure when the absorbance rasio $(260 \mathrm{~nm} / 280 \mathrm{~nm})=1,8-1,9[10,11]$. If the rasio value is under 1.8-1.9, it indicates that the samples are contaminated with protein, fenol, SDS, and polysaccharida $[11,12]$. Generally, the higher the DNA purity, the higher the
PCR sensitivity test [13]. The result described that Tacapa GB, Tacapa Silver, Action 434 have good DNA purity (1.803, 1.941, 1.832 perspectively), whereas Aramis purity is 1.648 (figure 2).

DNA concentration contributes to determinating dillution in DNA amplification. Optimization is the essential measure to determine the best concentration for PCR process. Huda [14] stated that the best DNA concentration for PCR process is $70 \mu \mathrm{g} / \mathrm{ml}$. The result shows that the highest DNA concentration figure is cultivar Tacapa Silver $(1.898 \mu \mathrm{g} / \mathrm{ml})$, whereas the lowest figure is Action $434(655 \mu \mathrm{g} / \mathrm{ml})$ (figure $3)$.

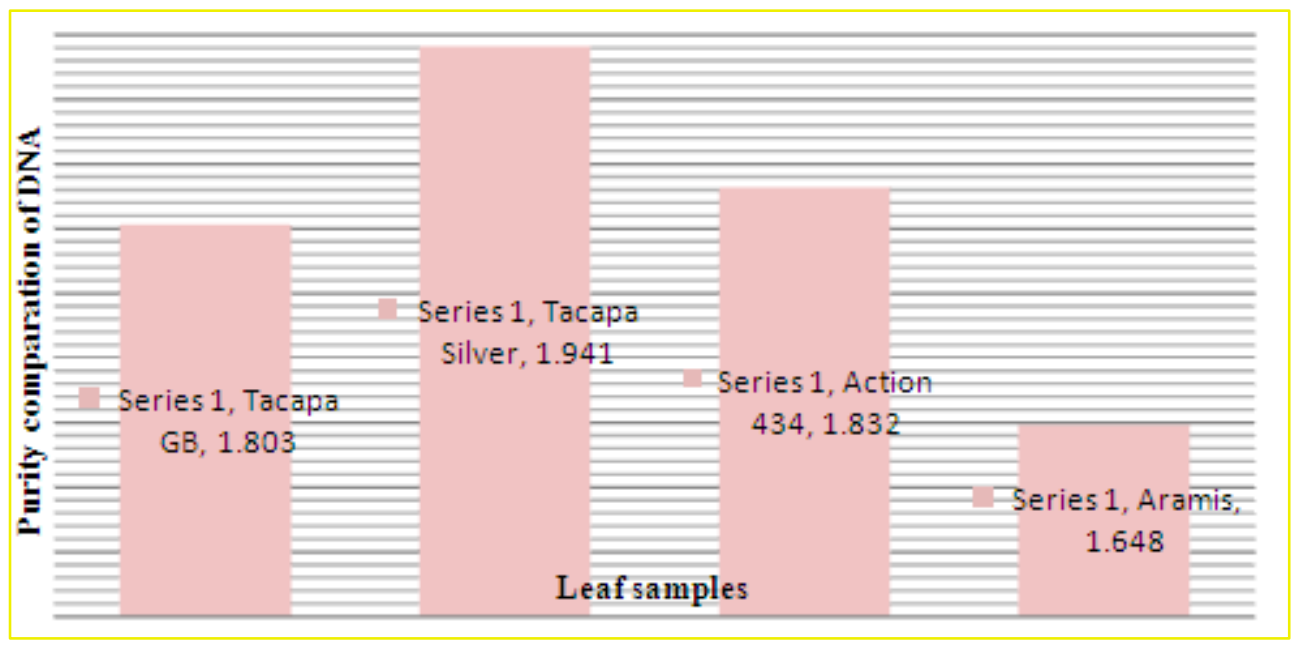

Figure 2. Purity comparation of DNA in melon cultivar Tacapa GB, Tacapa Silver, Action 434, and Aramis

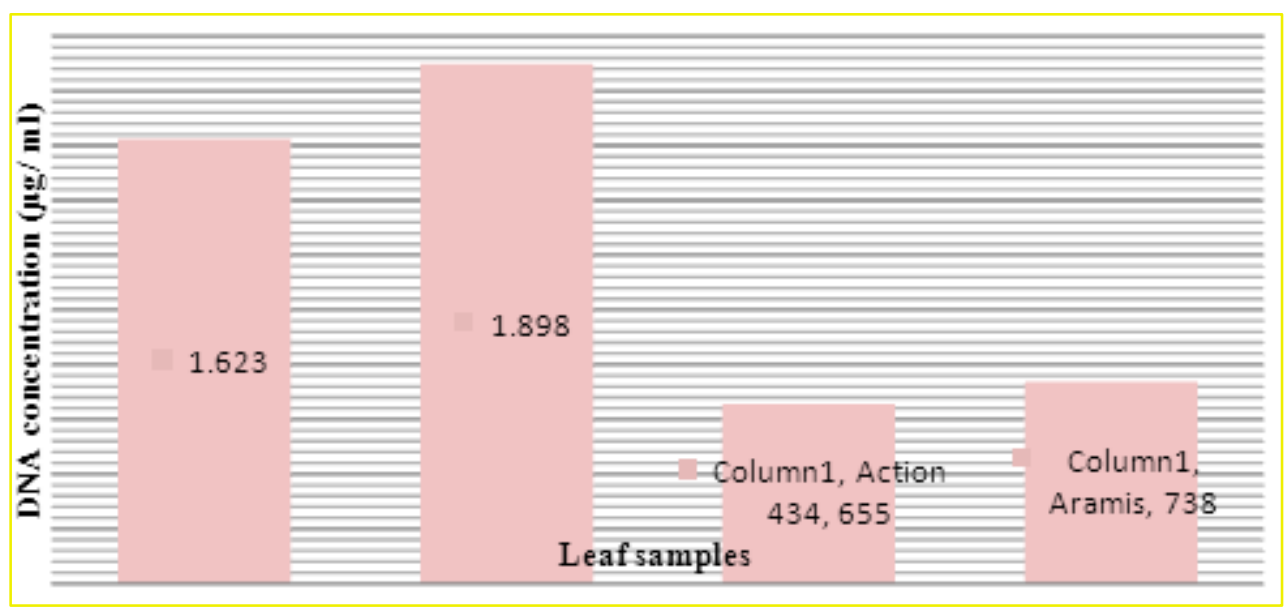

Figure 3. DNA concentration of melon cultivar Tacapa GB, Tacapa Silver, Action 434, and Aramis 


\subsection{Molecular Analysis Using SCAR Primer}

SCAR is specific primers that abridge the detection of DNA target. SCAR marker is developed from RAPD (Random Amplified Polymorphism DNA) amplified by pUBC411 marker [15] with adding 15 nucleotide from 10 RAPD nucleotide [9]. This marker can detect the gene precisely and accurately better than RAPD marker. Furthermore, it is more beneficial rather than inoculation process [3].

DNA amplification was carried out by PCR method. The target of gene could be observed by an emergence of amplified strip-DNA at 1058 base pair (bp). The PCR reaction was predenaturation at $95^{\circ} \mathrm{C}$ during 5 minutes, denaturation $95^{\circ} \mathrm{C}$ for 1 minute, annealing $56^{\circ} \mathrm{C}$ for 1 minute, elongation $72^{\circ} \mathrm{C}$ for 2 minutes, and post elongation $72^{\circ} \mathrm{C}$ for 10 minutes. Whereas, the optimization was tested at annealing temperature, DNA concentration, and primer concentration (Table 1).

Table 1. The optimization of annealing temperature, DNA concentration, and primer concentration

\begin{tabular}{|c|c|}
\hline Variabel / Primer & SCAR \\
\hline Annealing temperature & $56^{\circ} \mathrm{C}$ \\
\hline DNA concentration & $10 \mu \mathrm{M}$ \\
\hline Primer concentration & $1000-2000 \mu \mathrm{g} / \mathrm{ml}$ \\
\hline
\end{tabular}

Electrophoresis was aimed to separate DNA molecules based on the variety of weight. It used agarose gel by the concentration of $1.8 \%$. Afterwards, strip-DNA was observed through UV trans-illuminator. If the sample had resistance gene of Powdery Mildew, strip-DNA would be visible at $1058 \mathrm{bp}[10]$.

After examining under UV light by UV Trans-illuminator, Tacapa GB and Tacapa Silver have resistance gene of powdery mildew marked by the emergence of strip-DNA at $1058 \mathrm{bp}$. Whereas, the commercial melon cultivars (Action 434 and Aramis) do not have the resistance gene of powdery mildew due to the absence of strip-DNA at $1058 \mathrm{bp}$ (figure 4).

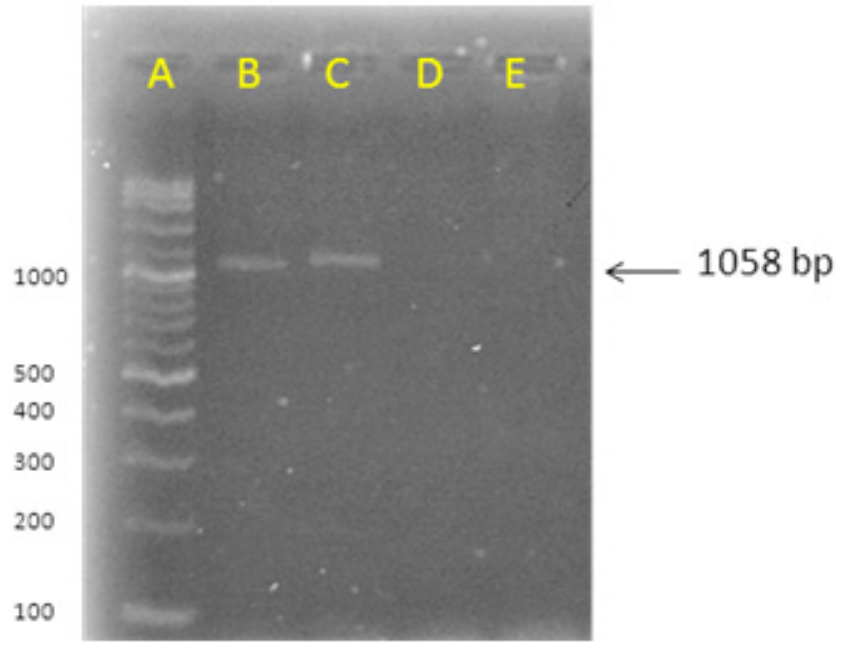

Figure 4. Result of electrophoresis; M: Marker (100bp) Vivantis; A: Tacapa GB; B: Tacapa Silver; C: Action; D. Aramis
The detected gene is $p m-W$ gene which is found in cultivar PI 371795 [17]. Hence, it can be concluded that the gene existing in cultivar Tacapa GB is inherited from its parental (PI 371795).

\subsection{Tenacity Time}

The presence of resistant gene againts powdery mildew supports the tenacity of Tacapa GB facing real condition in nature as shown at picture 6 . Tacapa GB has long tenacity reaching about 24 days in room temperature with characteristic fresh fruit, unleak, and absence of fungi and other microorganisms.

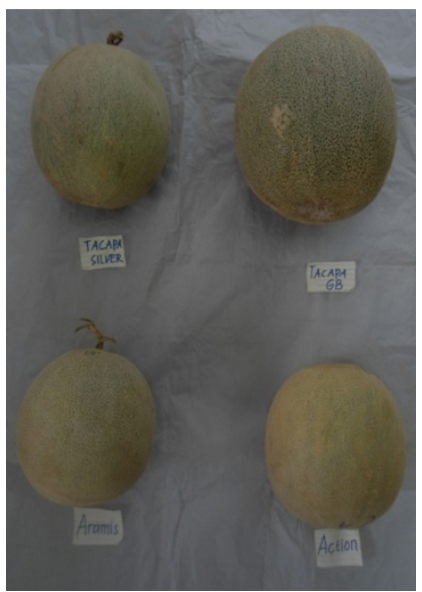

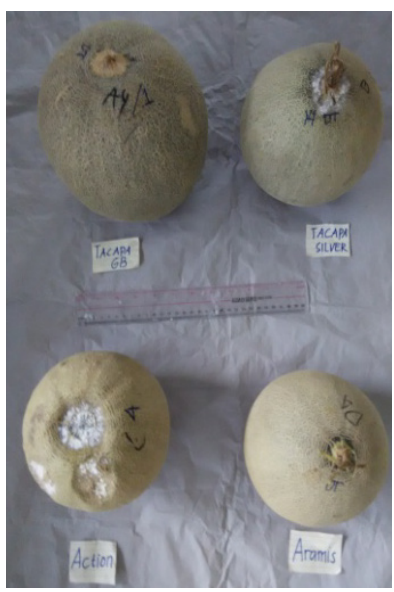

b
Figure 5. Tenacity time of melon cultivar Tacapa Green Black, Tacapa Silver, Action 434, and Aramis in (a) $1^{\text {st }}$ day and (b) $24^{\text {th }}$ day

In the development of melon production, the majority of people are dependent on utilizing pesticide to eradicate pests and diseases in the plant. Whereas, pesticides have negative impacts on the environment. Also, it can increase the fungi's resistence itself $[18,19]$. Tacapa GB becomes one of the best solutions dealing with this problem, because of the existence of the gene, it can handle pests and diseases naturally by itself.

\section{Conclusions}

Tacapa Green Black (GB) has powdery mildew resistance gene inherited from its parental (PI 371795). It is marked by the emergence of strip-DNA at 1058 base pair (bp).

\section{Acknowledgements}

Authors are completely grateful to all contributors for sharing reagents, valuable discussion, technical assistance, and criThis research was supported by PUSNAS Research Grant from Ministry of Research, Technology, and Higher Education, Republic of Indonesia No: 1072/UN1-P.III/LT/DIT-LIT/2016 


\section{REFERENCES}

[1] Sobir, M., and F.D Siregar. Excellent Melon Cultivation. Depok: Swadaya Publishing. 2010. p 10-11.

[2] Vegetable Production in Indonesia. 2013 [updated January 2016]. Available from: http://www.bps.go.id.

[3] Listiawan, D.A. Detection of Gene Against Powdery Mildew (podosphaera xanthii (Castagne) U. Braun \& N. Shishkoff) on Melon (Cucumis melo L.) used SCAR. Universitas Gadjah Mada.Thesis. 2009.

[4] Qurrohman, M. T. Analisys of Linked Gene Against Powdery Mildew on Testcross Melon Using SCAR Marker. Universitas Gadjah Mada.Thesis. 2011.

[5] Kuzuya, M., K. Yashiro, K. Tomita, and H. Ezura. Powdery mildew (Podosphaera xantii) resistance in melon is categorized into two types based on inhibition of the infection processes. Journal of Experimental Botany. 2006. 57 (9):2093-2100.

[6] Agrios, G.N. Plant Pathology Fifth Edition. Burlington: Elsevier Academic Press. 2005. p:448.

[7] Matheron, M.E and M. Porchas. Management of powdery mildew on cantaloupe. Journal Vegetable Report. 2004. (139):1-3

[8] Treuren, var. SCARs (Sequenced Characterized Amplified Regions). 2014. [Updated 2016]. Available from https://www.wageningenur.nl/en/show/Sequence-Characteri zed-Amplified-Region-SCAR.htm

[9] Daryono, B.S., G.R Aristya, and R.S. Kasiamdari. Development of random amplified polymorfism DNA markers linked to powdery mildew resistance gene ini melon. Indonesian Journal of Biotechnology. 2011. 16(2):76-82.

[10] Kolk A.H.J, L.F.F. Kox, L.J. van, and S. Kuijper. Polymerase chain reaction for the $\mathrm{M}$. tuberculosis complex. The

Netherland: Laboratory of Tropical Hygiene, Department of Biomedical Research Royal Tropical Institute, Amsterdam. 1995.

[11] Brown T.A. Gene cloning: an introduction. Workingham, Berkshire, England: Van Nostrand Reinhold (UK) Co Ltd Molly Millars Lane. 1986. p. 26

[12] Hill E.B., L.G. Wayne, and W.M. Gross. Curent practices in mycobacteriology: result of a survey of public health laboratories. J Bacteriol. 1972. (112):1033- 39.

[13] Rosilawati, M.L., P. Sudarmono, and F. Ibrahim. PCR Method Sensitivity Detecting Clinical Isolat Mycobacterium tuberculosis. J. Kedokteran Trisakti. 2002. (21):1.

[14] Huda, I. N. The Analysis of Genetic Variation of Melon (Cucumi melo L.) Cultivar Gama Melon Basket and Melodi Gama-1 by means of Random Amplified Polymorphic DNA Method. Universitas Gadjah Mada.Thesis. 2011.

[15] Fukino, N., M. Kunihisa, and S. Matsumoto. Characterization of Recombinant Inbred Lines Derived from Crosses in Melon (Cucumis melo L.), 'PMAR No.5' x 'Harukei No.3'. Breeding Science. 2004. (54): 141-145.

[16] Daryono, B. S. and M. T. Qurrohman. Inheritance of resistance to powdery mildew (Podosphaera xanthii (Castag.) Braun et Shishkoff) in melon (Cucumis melo L.). Jurnal Perlindungan Tanaman Indonesia, Jurnal Perlindungan Tanaman Indonesia. 2009. 15 (1): 1-6.

[17] Aristya, G.R., A. Agriansyah, and B.S. Daryono. Detection and Screening the inherintance character of Powdery Mildew resitance gene in backcros generation of Melon (Cucumis melo L.) var. Tacapa. Yogyakarta: Biology Faculty. Universitas Gadjah Mada. 2013.

[18] McGrath, M.T. Fungiside Resistance in Cucurbit Powdery Mildew: Experiences and Challenges. Plant Disease. 2001. (85): 236-245.

[19] Olalla, L. Etiologia, Biologia y Epidiomologia Del Odio de Las Cucurbitaceas en Cultivos Bajo Plastico. Thesis. Spain: Universidad de Malaga. 2001. 